\title{
Near-infrared laser desorption/ionization aerosol mass spectrometry for measuring organic aerosol at atmospherically relevant aerosol mass loadings
}

\author{
S. Geddes, B. Nichols, K. Todd, J. Zahardis, and G. A. Petrucci \\ Department of Chemistry, University of Vermont, Burlington, VT 05405 USA \\ Received: 19 April 2010 - Published in Atmos. Meas. Tech. Discuss.: 5 May 2010 \\ Revised: 29 July 2010 - Accepted: 19 August 2010 - Published: 31 August 2010
}

\begin{abstract}
A new method, near-infrared laser desorption/ionization aerosol mass spectrometry (NIR-LDI-AMS), is described for the real time analysis of organic aerosols at atmospherically relevant total mass loadings. Particles are sampled with an aerodynamic lens onto an aluminum probe. A moderate energy NIR laser pulse at $1064 \mathrm{~nm}$ is directed onto the probe to vaporize and ionize particle components. Delayed pulse extraction is then used to sample the ions into a reflectron time of flight mass spectrometer for chemical analysis. The soft ionization afforded by the NIR photons results in minimal fragmentation (loss of a hydrogen atom) producing intact pseudo-molecular anions at $[\mathrm{M}-\mathrm{H}]^{-}$. The limit of detection measured for pure oleic acid particles (geometric mean diameter and standard deviation of $180 \mathrm{~nm}$ and 1.3 , respectively) was $140 \mathrm{fg}$ (or $1.7 \mathrm{ng} \mathrm{m}^{-3}$ per minute sampling time). As an example of the utility of NIRLDI-AMS to measurements of atmospheric importance, the method was applied to laboratory chamber measurements of the secondary organic aerosol formation from ozonolysis of $\alpha$-pinene. High quality mass spectra were recorded with a 2-min time resolution for total aerosol mass loadings ranging from 1.5 to $8.7 \mu \mathrm{g} \mathrm{m}^{-3}$. These results demonstrate the potential of NIR-LDI-AMS to allow for more accurate measurements of the organic fraction of atmospheric particulate at realistic mass loadings. Measurements at ambient-levels of SOA mass loading are important to improve parameterizations of chamber-based SOA formation for modeling regional and global SOA fluxes and to aid in remediating the discrepancy between modeled and observed atmospheric total SOA production rates and concentrations.
\end{abstract}

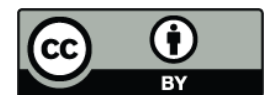

Correspondence to: G. A. Petrucci (giuseppe.petrucci@uvm.edu)

\section{Introduction}

Atmospheric aerosols have an important role in many atmospheric and environmental processes; exerting an influence on global and regional radiative energy balance, visibility, atmospheric circulation, the hydrological cycle, the regulation of greenhouse and reactive gases, and human health (Kanakidou et al., 2005; Pöschl, 2005; Seinfeld and Pankow, 2003). There is surmounting evidence that organic aerosols make a substantial contribution to the total mass of fine aerosols; contributing ca. $20-50 \%$ at continental mid-latitudes and up to $90 \%$ in tropical forested areas (Kanakidou et al., 2005). Also, organic compounds may have much higher localized contributions to aerosols during times of high biological activity, as recently observed for marine aerosols (O'Dowd et al., 2004; Meskhidze and Nenes, 2006; Yoon et al., 2007).

Secondary organic aerosols (SOA) make a significant contribution to the organic fraction, and total mass, of fine aerosols in the lower atmosphere. As discussed in a recent review on SOA (Hallquist et al., 2009), bottom-up estimates of global SOA production give total biogenic SOA fluxes of $12-70 \mathrm{Tg} \mathrm{yr}^{-1}$, and somewhat lower fluxes for anthropogenic SOA. These combine volatile organic compound (VOC) fluxes with laboratory-derived (e.g. chamber) data and typically estimate global SOA fluxes at about one to two orders lower than values derived from top-down (inverse) estimates, which are based in part on constraining the atmospheric fate of VOC precursors to SOA. The discrepancy in estimating global SOA fluxes between these two approaches highlights the need for a better understanding of the oxidative transformation of VOC precursors to SOA and the gasto-particle partitioning of these oxidation reaction products. In this regard, there has been a recent call for "an improved

Published by Copernicus Publications on behalf of the European Geosciences Union. 
understanding of the fundamental processes responsible for SOA formation and how they affect composition, and the design of simulation experiments which more closely reflect the conditions and complexity of the real atmosphere" (Hallquist et al., 2009). The research presented herein addresses these needs by developing an analytical tool of general utility to chamber-based studies that measures SOA as well as primary $\mathrm{OA}$ at atmospherically relevant total organic mass concentrations $\left(C_{\mathrm{OA}}\right)$.

Ambient organic aerosols are predominately composed of oxygenated organic compounds (i.e. OOA) (Jimenez et al., 2009) and continental levels of $C_{\mathrm{OA}}$ are typically less than ca. $10 \mu \mathrm{g} \mathrm{m}^{-3}$ (Jimenez et al., 2009; Cabada et al., 2004; Hock et al., 2008); however, traditional organic mass loadings of greater than $15 \mu \mathrm{g} \mathrm{m}^{-3}$ are used in most chamber-based studies. Most bottom-up estimates of SOA fluxes are based on parameterization of chamber-based SOA formation experiments done at these elevated organic mass loadings not representative of typical ambient concentrations. This limitation may be an important factor contributing to the discrepancy in modeled SOA fluxes between bottom-up and top-down models; moreover, it may, in part, lead to the inability of bottomup models to explain the observed atmospheric total SOA production rates and concentrations.

Several recent experimental studies have shown clearly the importance of characterizing SOA under atmospherically relevant organic particle mass loading. Shilling et al. (2009) characterized SOA particles derived from the dark ozonolysis of $\alpha$-pinene using an Aerodyne high-resolution timeof-flight aerosol mass spectrometer (HR-ToF-AMS) (Canagaratna et al., 2007; DeCarlo et al., 2006) coupled to a continuous-flow chamber. That study featured a wide-range of organic particle loadings (ca. 0.5 to $>140 \mu \mathrm{g} \mathrm{m}^{-3}$ ) and the mass spectra suggested more oxygenated organic material (i.e. a higher $\mathrm{O} / \mathrm{C}$ atomic ratio and density) in SOA at lower loading, which also had greater compositional variability compared to higher loadings typically employed in traditional chamber experiments. As noted in that work (Shilling et al., 2009), these experiments suggest that the extrapolation of results derived from chamber-based studies obtained under relatively high loading of the organic particle phase may be inappropriate for modeling SOA formation in the atmosphere where lower loadings are typical.

The high sensitivity, relatively fast time response and low fragmentation afforded by proton-transfer reaction mass spectrometry (PTR-MS) make it an attractive tool for realtime measurements of VOCs in the atmosphere (de Gouw and Warneke, 2006), as well as the monitoring of VOCs and semivolatile organic compounds (SVOCs) in laboratorybased SOA formation experiments (Presto and Donahue, 2006; $\mathrm{Ng}$ et al., 2007). For example, Presto and Donahue (Presto and Donahue, 2006) coupled PTR-MS measurements of gas-phase VOCs with particle based measurements (i.e. monitored by a scanning mobility particle sizer, SMPS) to investigate SOA production from the ozonolysis of $\alpha$-pinene at atmospherically relevant total organic mass concentration (i.e. $C_{\mathrm{OA}}<10 \mu \mathrm{g} \mathrm{m}^{-3}$ ). The results of that study showed that extrapolations of current models to atmospheric $C_{\mathrm{OA}}$ levels significantly underestimate SOA under dark, low- $\mathrm{NO}_{\mathrm{x}}$ conditions, while conversely, overestimating SOA production under illuminated, higher- $\mathrm{NO}_{\mathrm{x}}$ conditions typical of polluted areas. PTR-MS has also been adapted to the measurement of particulate phase organics, for real-time chamber-based studies, albeit at high $C_{\mathrm{OA}}$ (Hellén et al., 2008), and very recently for organic particles collected from both chamberbased studies and field observations (Holzinger et al., 2010) by combining PTR-MS with a collection-thermal-desorption (TD) aerosol sampling technique. In this latter study, the reported detection limit of aerosol compounds was $35 \mathrm{pg}$ (or $0.2 \mathrm{ng} \mathrm{m}^{-3}$ for a reported aerosol collection time of approximately three hours) (Holzinger et al., 2010) making TDPTR-MS a potentially powerful tool for the characterization of SOA at low total organic mass loadings.

As has been discussed in several reviews (Noble and Prather, 2000; Nash et al., 2006; Hunt and Petrucci, 2002), a number of different pulsed-laser ionization methods have been used as ionization sources for AMS. Laser desorption/ionization (LDI), an attractive ionization source because of its versatility and high sensitivity (due to the large number of photons per pulse i.e. irradiance between $\sim 10^{6}$ to $10^{12} \mathrm{~W} \mathrm{~cm}^{-2}$ ) (Hunt and Petrucci, 2002), has been coupled with time-of-flight (TOF) mass spectrometry for the analysis of aerosols since the early 1990s (Mansoori et al., 1994; McKeown et al., 1991; Prather et al., 1994). To date, UV LDI has typically been coupled to AMS (see the aforementioned reviews and references), which often results in significant fragmentation of the organic constituents of particles. However, the reduced fragmentation of organic components of particles has been demonstrated by employing infrared radiation for desorption of organic compounds followed by ionization of the vaporized species by UV-radiation in twostep laser desorption/ionization methods (Woods III et al., 2001; Öktem et al., 2004).

In this work we present a new methodology suitable to the analysis of atmospheric aerosols that integrates the strategies of matrix-free LDI with AMS. Matrix-free LDI methods utilizing pulsed UV lasers include desorption/ionization on silicon (DIOS) (Shen et al., 2001; Thomas et al., 2001; Wei et al., 1999), as well as other surfaces, such as metals (e.g. aluminum (Hsu et al., 2008), porous alumina (Nayak and Knapp, 2007) and stainless steel (Hsu et al., 2008)). Most of the aforementioned works have placed emphasis on the analysis of proteins and other biomolecules measured in positive ion mode (Bhattacharya et al., 2002; Rousell et al., 2004); however, there are a limited number of reports of matrix-free UV-LDI methods operating in negative ion mode (Srivastava et al., 2005; Wada et al., 2007). In the majority of matrixfree LDI studies reported, the best results in terms of signal level and low-mass interference were obtained with the use of mid-infrared (ca. $3 \mu \mathrm{m}$ ) laser radiation on silicon surfaces 
(Bhattacharya et al., 2002; Rousell et al., 2004). The following report demonstrates the advantages of surface mediated LDI using single-wavelength near-infrared (NIR) radiation for both desorption and ionization in AMS. This report focuses on the detection of negative ions, $[\mathrm{M}-\mathrm{H}]^{-}$, that are derived from the loss of hydrogen from weakly acidic organic species (i.e. carboxylic acids and aldehydes) common to atmospheric primary and secondary organic aerosols. The high sensitivity we have observed coupled to the minimal fragmentation of these species makes it an ideal method for the analysis of complex, multicomponent organic particles, including SOA particles.

\section{Experimental}

\subsection{Near-Infrared Laser Desorption/Ionization-Aerosol Mass Spectrometry (NIR-LDI-AMS)}

A LDI based aerosol mass spectrometer (Fig. 1) has been developed in which a Liu-type aerodynamic lens (Liu et al., 1995a, b) is used to produce a collimated particle beam, with a diameter less than $0.3 \mathrm{~mm}$ (FWHM, as measured by laser scatter) that is directed onto the concave surface of a floating potential, $1 \mathrm{~mm}$ diameter aluminum wire probe $(99.9 \% \mathrm{pu}-$ rity, Alfa-Aesar Chemicals, Ward Hill, MA) held centrally in the ion extraction region of a reflectron time of flight mass spectrometer (R. M. Jordan Inc., Grass Valley, CA). The mass spectrometer was configured to operate in the negative ion mode, with all ions detected as $[\mathrm{M}-\mathrm{H}]^{-}$anions. It should be noted that the probe was exchanged for a fresh probe between experiments through a vacuum-load-lock that permits changing the probe on a timescale of minutes without breaking vacuum. This allows for the collection of reproducible NIR-LDI mass spectra between different chamber-based experiments and minimizes any effects due to aging of the wire. A 100- $\mu$ m diameter critical orifice (O'Keefe Controls, Monroe, CT) at the entrance of the inlet maintains a constant aerosol sampling flow rate of $83 \mathrm{~cm}^{3} \mathrm{~min}^{-1}$.

Following particle collection for a prescribed time, desorption and ionization are performed by a single $1064 \mathrm{~nm}$ laser pulse ( $5 \mathrm{~ns}$ ) produced by a Nd-YAG laser (Model Brio, Quantel, Big Sky, CO) incident on the surface of the Al probe at approximately 30 degrees from normal. The laser passes through a high energy beam attenuator (Model 935-5OPT, Newport, CA) offering fine control of the pulse energies and is steered directly into the ionization chamber (i.e. with no additional focusing). The laser spot size (diameter $\sim 3 \mathrm{~mm}$ ) is larger than the $\mathrm{Al}$ probe surface ensuring small variations in beam direction have minimal effect on the desorption/ionization process. Laser pulse energies were 25 to $35 \mathrm{~mJ}$ per pulse, resulting in fluence at the probe surface from 70 to $100 \mathrm{MW} \mathrm{cm}^{-2}$. A separate $\mathrm{CW} 532 \mathrm{~nm}$ laser (Viasho VA-I-N-532, Beijing, China) is aligned in front of the $\mathrm{Al}$ wire

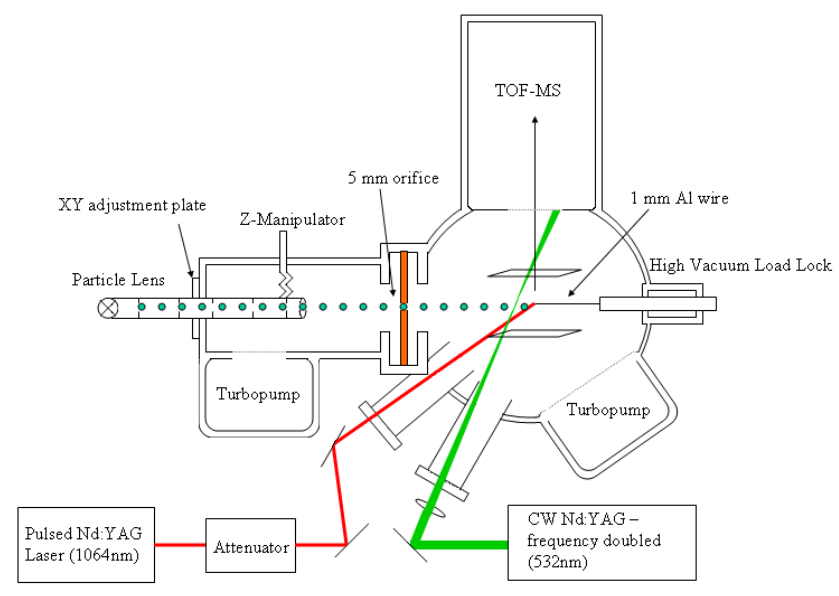

Fig. 1. Schematic drawing of NIR-LDI-AMS.

probe in order to assist with initial particle beam alignment, but is not in used during mass spectral measurements.

A pulse generator (DG535 from Stanford Research Instruments, Sunnyvale, CA) is used to control the delay time between laser Q-switch trigger and the ion extraction pulsed power supply (Model PVM-4210, Directed Energy, Inc., Fort Collins, CO). Typical delay times of 5-8 $\mu$ s are used in order to reduce the high energy ion signals observed to originate directly from the $\mathrm{Al}$ wire and obtain the pseudo-molecular ions of the adsorbed molecules as described below. Mass spectral data was acquired at $1 \mathrm{GS} \mathrm{s}^{-1}$ with a digital oscilloscope (WavePro 7000, LeCroy, Chestnut Ridge, NY), which currently limits data acquisition to one mass spectrum (i.e. laser firing) per second.

\subsection{Particle formation and processing}

Pure oleic acid particles were utilized as a proxy for POA. Particles were generated by homogeneous nucleation of oleic acid (Malinckrodt Chemicals, Phillipsburg, NJ) vapor generated in a small flask held at $110^{\circ} \mathrm{C}$ and flushed through a condenser by a flow of zero air (USP Medical Air, Airgas East, Williston, VT) into a small, $0.5 \mathrm{~m}^{3}$ Teflon chamber. Aerosol particle number and mass size distributions were measured with a scanning mobility particle sizer (SMPS: Model SMPS 3080, TSI Inc., Shoreview, MN). Aerosol (number) geometric mean diameter and standard deviation were typically on the order of $180 \mathrm{~nm}$ and 1.3 , respectively.

Secondary particles generated from the ozonolysis of $(+)-\alpha$-pinene $(98 \%$, Sigma-Aldrich) were used as proxies to SOA. SOA particles were formed in the recently developed University of Vermont Environmental Chamber (UVMEC, 5.0 mil TeflonR FEP, Welch Fluorocarbon, Dover, $\mathrm{NH}$ ) with a volume of $8 \mathrm{~m}^{3}$ operated in batch-mode. The Teflon UVMEC is equipped with separate gas and particle inlets, mixing fan, and filter sampling ports. A combined temperature/RH probe (Vaisala HMT331, Woburn, MA) is 


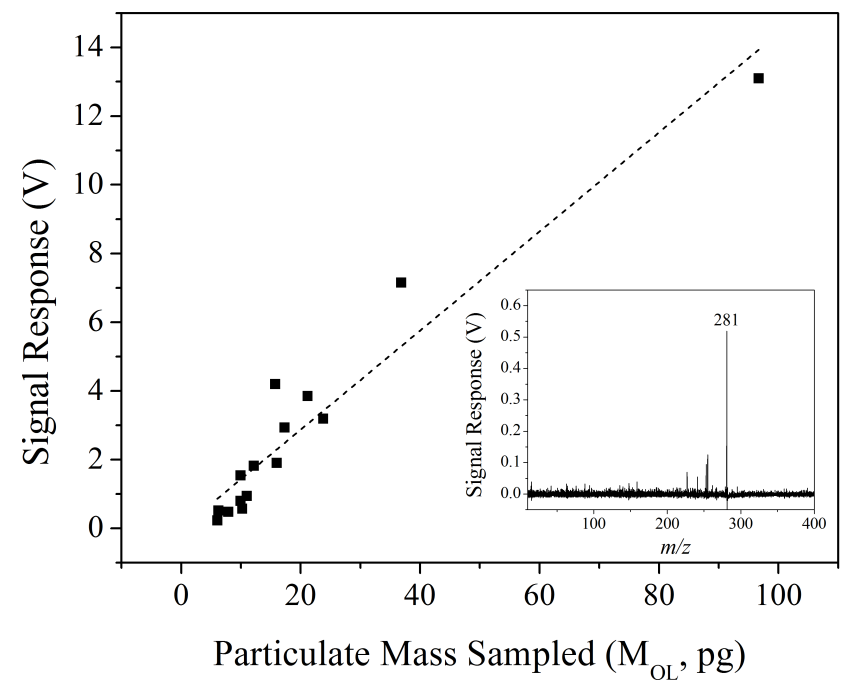

Fig. 2. Calibration curve for pure oleic acid particles (geometric mean diameter and standard deviation of $180 \mathrm{~nm}$ and 1.3 , respectively). Equation of line is $\mathrm{S}=0.144 \mathrm{M}_{\mathrm{OL}}-0.0113$. Black squares represent single measurements taken. Inset: NIR-LDI-AMS spectrum of oleic acid particles sampled from an aerosol with mass loading of $0.15 \mu \mathrm{g} \mathrm{m}^{-3}$ for $30 \mathrm{~s}$ (7.5 pg total mass sampled).

mounted on the interior of the chamber with all of the following experiments conducted indoors at room temperature. The $\alpha$-pinene was introduced to the chamber by evaporating the required amount of hydrocarbon in a small flask held in a water bath through which a small flow rate of zero air was flushed into the chamber. After loading the hydrocarbon into the chamber, the formation of SOA was initiated by the addition of a short burst of ozone generated from dry, particle free air by a commercial high frequency corona discharge ozone generator (OL80A/DLS, OzoneLab, Burton, BC, Canada). The $\mathrm{O}_{3}$ was quickly flushed into the chamber and simultaneously quantified with an ambient level monitor (Serinus $\mathrm{O}_{3}$ Model E020010, American Ecotech, Cincinnati, OH). $\mathrm{NO}_{\mathrm{x}}$ levels (as $\mathrm{NO}$ and $\mathrm{NO}_{2}$ ) in the chamber were monitored with a commercial detector (EC9041A NOx Analyser, American Ecotech, Cincinnati, $\mathrm{OH}$ ) throughout the experiment, with concentrations less than 5 ppbv throughout these experiments.

SOA particle number and mass size distributions were measured as previously described for POA particles using the SMPS directly before introduction into the mass spectrometer through the particle inlet and lens system. In the following experiments polydisperse SOA particles were analyzed by NIR-LDI-AMS, with the mean diameter changing over the course of the experiment, and stated within the appropriate figure captions.

\section{Results and discussion}

\subsection{Primary Organic Aerosols (POA)}

The signal response of NIR-LDI-AMS for oleic acid ( $282 \mathrm{u})$ was monitored for the $281 \mathrm{~m} / z$ pseudo-molecular ion, [OL$\mathrm{H}]^{-}$, which was the base peak in the mass spectrum (Fig. 2). A linear response was measured for $[\mathrm{OL}-\mathrm{H}]^{-}$signal (S) as a function of POA mass deposited $\left(\mathrm{M}_{\mathrm{OL}}\right)$. For these measurements, oleic acid aerosol mass loadings ranged from 0.15 to $4.4 \mu \mathrm{g} \mathrm{m}^{-3}$. Particles were deposited onto the LDI probe for variable times $(5-30 \mathrm{~s})$ to achieve total mass depositions in the range of 7 to $97 \mathrm{pg}$. The instrumental limit of detection $(3 \sigma)$ is $0.14 \mathrm{pg}$ (or $140 \mathrm{fg}$ ), a significant improvement over existing soft ionization methods for on-line, organic aerosol analysis, such as PIAMS (Öktem et al., 2004), TD-PTRMS (Holzinger et al., 2010) and PERCI-AMS (LaFranchi and Petrucci, 2006), which was recently developed in our laboratory. The enhanced performance of NIR-LDI-AMS compared to that of PERCI-AMS likely is a result of the improved spatial and temporal overlap of the vaporization and ionization processes that is afforded by utilizing a single laser pulse.

For the case of oleic acid and other fatty acids, which often have elevated concentrations as high as 1 to $5 \mathrm{ng} \mathrm{m}^{-3}$ in urban environments (Robinson et al., 2006; Fraser et al., 2002; Zheng et al., 2002), collection of ambient aerosols on the timescale of several minutes would be required to achieve this LOD. Since ambient loading of other low-volatility, oxygenated molecular markers common to urban aerosols, such as cholesterol and palmitoleic acid, often have atmospheric concentrations of the same order as oleic acid, our current research emphasis is on establishing the LOD of these and other species of atmospheric relevance. Initial measurements suggest an analytical performance analogous to that of oleic acid.

\subsection{Secondary Organic Aerosols (SOA)}

As proof of utility of the NIR-LDI-AMS to the measurement of atmospheric aerosols at ambient levels, the system was used to analyze SOA particles resulting from the ozonolysis of $\alpha$-pinene. This system was chosen for these preliminary applications of NIR-LDI-AMS to chamber-based SOA measurements because it has been the focal point of numerous recent chamber-based studies of SOA formation and growth (please see recent reviews on SOA by Hallquist et al., 2009, and Kroll and Seinfeld, 2008). SOA formation was initiated by the injection of $25 \mu \mathrm{L}$ of $\alpha$-pinene into the UVMEC, to achieve a mixing ratio of $500 \mathrm{ppbv}$, and subsequent addition of a burst of ozone to an initial measured concentration of $750 \mathrm{ppbv}$. The ozone concentration decreased to $500 \mathrm{ppbv}$ over the next hour (Fig. 3a), representing a pseudo steady state for $\mathrm{O}_{3}$. SOA was sampled during this hour, while simultaneously monitoring the total organic mass concentration, 

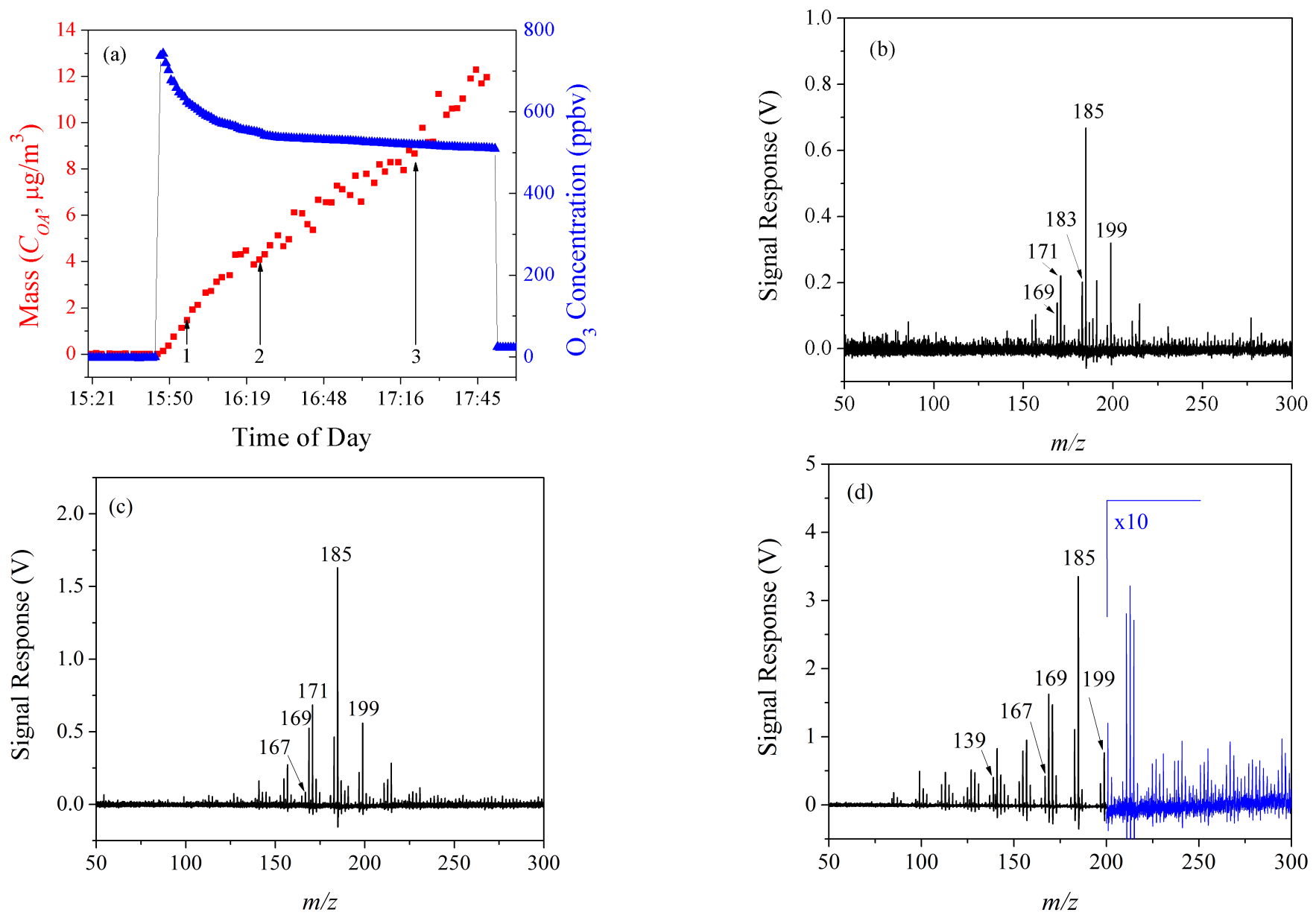

Fig. 3. Typical time-course data recorded during SOA formation in chamber from $\alpha$-pinene ozonolysis, including (a) total aerosol mass loading ( $\mathbf{\square}), C_{\mathrm{OA}}$, ozone concentration $(\mathbf{\Lambda})$ and NIR-LDI mass spectra at three different time points along the SOA growth curve; (b) Time point 1 with $C_{\mathrm{OA}}=1.5 \mu \mathrm{g} \mathrm{m}^{-3}$; aerosol (number) geometric mean diameter of $132 \mathrm{~nm}$ and standard deviation of 1.31 ; (c) Time point 2 with $C_{\mathrm{OA}}=4.1 \mathrm{\mu g} \mathrm{m}^{-3}$; aerosol (number) geometric mean diameter of $168 \mathrm{~nm}$ and standard deviation of 1.30 ; (d) Time point 3 with $C_{\mathrm{OA}}=8.7 \mu \mathrm{g} \mathrm{m}^{-3}$; aerosol (number) geometric mean diameter of $197 \mathrm{~nm}$ and standard deviation of 1.30 . Each mass spectrum is the result of a single, 2-min aerosol sampling into the NIR-LDI-AMS.

$C_{\mathrm{OA}}$. Notably, $C_{\mathrm{OA}}$ ranged from 1.6 to $12 \mu \mathrm{g} \mathrm{m}^{-3}$ for all measurements, which is within the reported range of total mass concentration of organic components of continental submicron aerosols (Jimenez et al., 2009; Cabada et al., 2004; Hock et al., 2008). Figure 3b-d shows temporally correlated NIR-LDI mass spectral data from a typical $\alpha$-pinene SOA experiment performed at these atmospherically relevant mass loadings.

The results obtained in this study highlight the utility of NIR-LDI-AMS for determining components of SOA in chamber-based experiments under conditions of atmospherically relevant mass concentrations of total particulate phase. The following discussion focuses on the prominent NIR-LDI ion signals that for the most part correspond with well-known products in $\alpha$-pinene SOA to establish the utility of the novel NIR-LDI-AMS technique for monitoring SOA in chamberbased studies. More comprehensive discussions of the chem- ical composition and mechanisms associated with $\alpha$-pinene SOA are given in references cited below as well as numerous reports summarized in recent reviews (Kroll and Seinfeld, 2008; Hallquist et al., 2009). The base peak in all trials in this and other experiments is $185 \mathrm{~m} / \mathrm{z}$, which is assigned to cis-pinic acid. The molecular structure of pinic acid and the other products measured are given in Table 1. A synthetic standard of cis-pinic acid was analyzed by NIR-LDI-AMS as deposited POA to support this assignment by insuring that this dicarboxylic acid did not extensively fragment in the desorption and ionization process. Another very strong ion signal in all collected spectra was $183 \mathrm{~m} / z$, assigned to another major ozonolysis product of $\alpha$-pinene, cis-pinonic acid. As noted by Hallquist et al. (2009) both cis-pinic acid and cispinonic acid are well established as major ozonolysis products of $\alpha$-pinene and may also be produced from reactions of $\alpha$-pinene with $\mathrm{OH}$ radical. Figure 4 shows the ion intensity, 
Table 1. Particle-phase products of $\alpha$-pinene ozonolysis measured by NIR-LDI-AMS as the $[\mathrm{M}-\mathrm{H}]^{-}$pseudo-molecular ions. $(*)$ Tentative assignment to one of several possible isomers (see text for further discussion).

2,3-dimethyl-cyclobutane-1,3-dicarbaldehyde

$I_{N}$, of cis-pinonic acid and other important products normalized to pinic acid (base peak). It should be noted that the assignment of the $183 \mathrm{~m} / \mathrm{z}$ ion to cis-pinonic acid does not disallow for the contribution of other isomers to this ion signal. For example, possible contributors to the $183 \mathrm{~m} / \mathrm{z}$ ion signal include the stereoisomers of OH-pinonaldehyde (184u), which have been suggested products of $\alpha$-pinene ozonolysis and contributors to SOA (Glasius et al., 2000; Iinuma et al., 2004; Camredon et al., 2010). The stereoisomers of $\mathrm{OH}-$ pinonaldehyde may arise from the gas-phase hydroxylation of pinonaldehyde (168 u) (Larsen et al., 2001), which was detected by NIR-LDI-AMS as a weak-to-medium intensity ion signal at $167 \mathrm{~m} / \mathrm{z}$. Furthermore, the strong $199 \mathrm{~m} / \mathrm{z}$ ion signal suggests $\mathrm{OH}$-radical initiated reactions with the $184 \mathrm{u}$ product(s), giving $200 \mathrm{u}(199 \mathrm{~m} / \mathrm{z})$ products that contain carboxyl moieties. The $\mathrm{OH}$-radical initiated oxidation of $\mathrm{OH}-$ pinonaldehyde isomers $(184 \mathrm{u})$ could give rise to $200 \mathrm{u}$ products, namely the isomers of $\mathrm{OH}$-pinonic acid (Table 1). $\mathrm{OH}$ pinonic acid (i.e. hydroxypinonic acid) has been reported as a product in SOA derived from the ozonolysis of $\alpha$-pinene (Gao et al., 2004; Tolocka et al., 2006; Yu et al., 1999; Camredon et al., 2010) and has been suggested to be a po- tential building block for higher molecular weight oligomers (Tolocka et al., 2006). Figure 3d shows the NIR-LDI ion signal for higher molecular weight products (note scale change), which may include oligomers and that increases with reaction time. Similarly, the strong ion signal at $171 \mathrm{~m} / \mathrm{z}$ ion is assigned to norpinic acid $(172 \mathrm{u})$, which has been reported in other chamber-based studies (Yu et al., 1999; Camredon et al., 2010; Glasius et al., 2000). This dicarboxylic acid may arise from a multiple step mechanism initiated by the $\mathrm{OH}$ oxidation of a dialdehyde. A logical candidate dialdehyde precursor to norpinic acid is 2,3-dimethyl-cyclobutane-1,3dicarbaldehyde $(140 \mathrm{u})$. The presence of this $140 \mathrm{u}$ dialdehyde is supported by the moderate intensity $139 \mathrm{~m} / \mathrm{z}$ ion signal in the NIR-LDI mass spectra. Other products shown in Table 1 include the $169 \mathrm{~m} / \mathrm{z}$ ion that is assigned to pinalic and norpinonic acid $(170 \mathrm{u})$, both of which having been reported in previous chamber studies (Larsen et al., 2001; Yu et al., 1999; Glasius et al., 2000), as well as a prominent unidentified product at $173 \mathrm{~m} / \mathrm{z}$. 


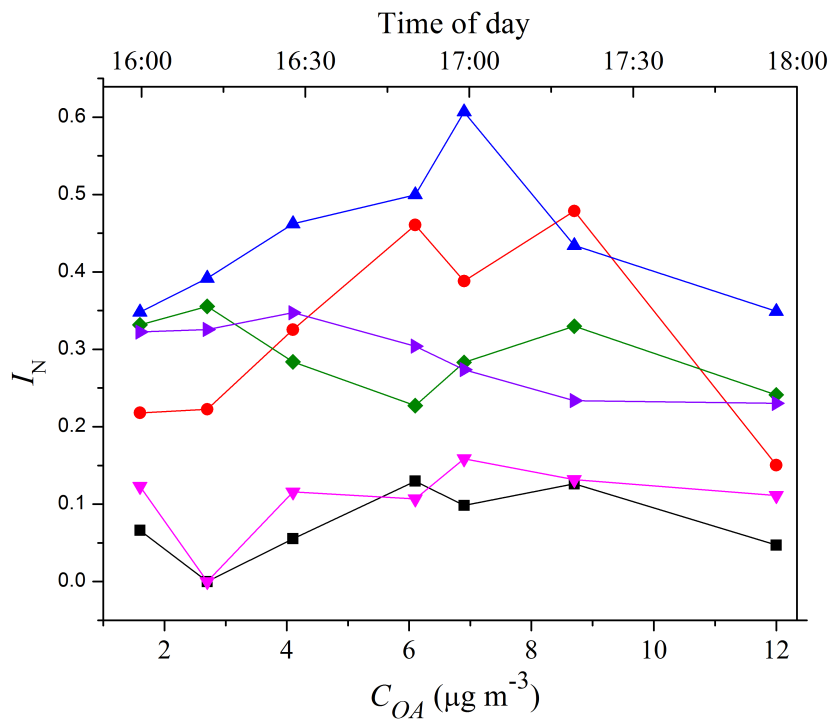

Fig. 4. Graph showing the ion intensity, $I_{N}$, of various $m / z$ peaks (normalized to the ion intensity of pinic acid) at evolving $C_{\mathrm{OA}}$ values as measured by NIR-LDI-AMS for the ozonolysis of $\alpha$-pinene:

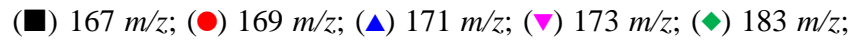
(๖) $199 \mathrm{~m} / \mathrm{z}$; see Fig. 3a for detailed particle mass concentrations and Table 1 for $m / z$ assignments.

\section{Conclusions}

This report has presented preliminary results for the analysis of organic aerosols by a new analytical technique with direct applicability to atmospheric science, namely: nearinfrared laser desorption/ionization aerosol mass spectrometry. This method has been shown to have limits of detection in the mid-to-low fg range, corresponding to total analysis times on the order of several minutes for SOA mass loadings on the order of a few $\mu \mathrm{g} \mathrm{m}^{-3}$. This detection limit represents an improvement of over two orders of magnitude from most other laser-driven "soft" ionization methods applied to AMS, such as VUV photoionization (Öktem et al., 2004) and PERCI-AMS (LaFranchi and Petrucci, 2006). A current effort is underway to assess the relative analytical figures of merit for NIR-LDI-AMS for a full-range of representative compounds common to ambient POA and SOA, including organic acids, high-molecular weight esters, and sterols. The results presented herein were determined with the mass spectrometer operating in negative ion mode with all reported and observed ions in the $[\mathrm{M}-\mathrm{H}]^{-}$form. However, preliminary measurements with the mass spectrometer configured in positive ion mode have detected $[\mathrm{M}+\mathrm{H}]^{+}$ions for aerosols composed of organic bases (e.g. aliphatic amines) which suggests that the general utility of NIR-LDI-AMS for the analysis of atmospheric organic aerosols will be enhanced by incorporation of a bipolar mass spectrometer with the NIR-LDI source. This will permit the simultaneous detection of a wide variety of compounds common to the organic fraction of at- mospheric aerosols; including weak organic acids (e.g. carboxylic acids, aldehydic compounds) and organic bases (e.g. amines) as $[\mathrm{M}-\mathrm{H}]^{-}$and $[\mathrm{M}+\mathrm{H}]^{+}$ions, respectively.

The utility of NIR-LDI-AMS for chamber-based SOA formation studies was clearly demonstrated. The detection of important known SOA products arising from ozonolysis of $\alpha$-pinene, including cis-pinic and cis-pinonic acid, at $C_{\mathrm{OA}}$ values from $<1 \mu \mathrm{g} \mathrm{m}^{-3}$ to $12 \mu \mathrm{g} \mathrm{m}^{-3}$ is within the reported range of total mass concentration of organic components of continental submicron aerosols (Jimenez et al., 2009; Cabada et al., 2004; Hock et al., 2008). The development and advancement of methods, such as NIR-LDI-AMS, will help the atmospheric research community simulate and measure SOA formation and growth under conditions that more closely represent the actual atmosphere. Ultimately, these advancements to atmospheric measurement techniques may help facilitate more accurate parameterizations of chamber-based SOA formation for modeling regional and SOA fluxes and aid in remediating the discrepancy between modeled and observed atmospheric total SOA production rates and concentrations.

Acknowledgements. The authors gratefully acknowledge funding for this work from the National Science Foundation (ATM-092502).

Edited by: D. Toohey

\section{References}

Bhattacharya, S. H., Raiford, T. J., and Murray, K. K.: Infrared laser desorption/ionization on silicon, Anal. Chem., 74, 2228-2231, 2002.

Cabada, J. C., Rees, S., Takahama, S., Khlystov, A., Pandis, S. N., Davidson, C. I., and Robinson, A. L.: Mass size distributions and size resolved chemical composition of fine particulate matter at the Pittsburgh supersite, Atmos. Environ., 38, 3127-3141, 2004.

Camredon, M., Hamilton, J. F., Alam, M. S., Wyche, K. P., Carr, T., White, I. R., Monks, P. S., Rickard, A. R., and Bloss, W. J.: Distribution of gaseous and particulate organic composition during dark ?-pinene ozonolysis, Atmos. Chem. Phys., 10, 2893 2917, doi:10.5194/acp-10-2893-2010, 2010.

Canagaratna, M. R., Jayne, J. T., Jimenez, J. L., Allan, J. D., Alfarra, M. R., Zhang, Q., Onasch, T. B., Drewnick, F., Coe, H., Middlebrook, A., Delia, A., Williams, L. R., Trimborn, A. M., Northway, M. J., DeCarlo, P. F., Kolb, C. E., Davidovits, P., and Worsnop, D. R.: Chemical and microphysical characterization of ambient aerosols with the Aerodyne aerosol mass spectrometer, Mass Spectrom. Rev., 26, 185-222, 2007.

de Gouw, J. and Warneke, C.: Measurements of volatile organic compounds in the Earth's atmosphere using proton-transferreaction mass spectrometry, Mass Spectrom. Rev., 26, 223-257, doi:10.1002/mas.20119, 2006.

DeCarlo, P. F., Kimmel, J. R., Trimborn, A., Northway, M. J., Jayne, J. T., Aiken, A. C., Gonin, M., Fuhrer, K., Horvath, T., Docherty, K. S., Worsnop, D. R., and Jimenez, J. L.: Field-deployable, high-resolution, time-of-flight aerosol mass spectrometer, Anal. Chem., 78, 8281-8289, 2006. 
Fraser, M. P., Yue, Z. W., Tropp, R. J., Kohl, S. D., and Chow, J. C.: Molecular composition of organic fine particulate matter in Houston, TX, Atmos. Environ., 36, 5751-5758, 2002.

Gao, S., Keywood, M., Ng, N. L., Surratt, J., Varutbangkul, V., Bahreini, R., Flagan, R. C., and Seinfeld, J. H.: Low-molecularweight and oligomeric compounds in secondary organic aerosol from the ozonolysis of cycloalkenes and $\alpha$-pinene, J. Phys. Chem. A, 108, 10147-10164, 2004.

Glasius, M., Lahaniati, M., Calogirou, A., Di Bella, D., Kotzias, D., and Larsen, B. R.: Carboxylic acids in secondary aerosols from oxidation of cyclic monoterpenes by ozone, Environ. Sci. Technol., 34, 1001-1010, 2000.

Hallquist, M., Wenger, J. C., Baltensperger, U., Rudich, Y., Simpson, D., Claeys, M., Dommen, J., Donahue, N. M., George, C., Goldstein, A. H., Hamilton, J. F., Herrmann, H., Hoffmann, T., Iinuma, Y., Jang, M., Jenkin, M. E., Jimenez, J. L., Kiendler-Scharr, A., Maenhaut, W., McFiggans, G., Mentel, Th. F., Monod, A., Prévôt, A. S. H., Seinfeld, J. H., Surratt, J. D., Szmigielski, R., and Wildt, J.: The formation, properties and impact of secondary organic aerosol: current and emerging issues, Atmos. Chem. Phys., 9, 5155-5236, doi:10.5194/acp-95155-2009, 2009.

Hellén, H., Dommen, J., Metzger, A., Gascho, A., Duplissy, J., Tritscher, T., Prevot, A. S. H., and Baltensperger, U.: Using proton transfer reaction mass spectrometry for online analysis of secondary organic aerosols, Environ. Sci. Technol., 42, 73477353, 2008.

Hock, N., Schneider, J., Borrmann, S., Römpp, A., Moortgat, G., Franze, T., Schauer, C., Pöschl, U., Plass-Dülmer, C., and Berresheim, H.: Rural continental aerosol properties and processes observed during the Hohenpeissenberg Aerosol Characterization Experiment (HAZE2002), Atmos. Chem. Phys., 8, 603-623, doi:10.5194/acp-8-603-2008, 2008.

Holzinger, R., Williams, J., Herrmann, F., Lelieveld, J., Donahue, N. M., and Röckmann, T.: Aerosol analysis using a ThermalDesorption Proton-Transfer-Reaction Mass Spectrometer (TDPTR-MS): a new approach to study processing of organic aerosols, Atmos. Chem. Phys., 10, 2257-2267, doi:10.5194/acp10-2257-2010, 2010.

Hsu, N.-Y., Tseng, S. Y., Wu, C.-Y., Ren, C.-T., Lee, Y.-C., Wong, C.-H., and Chen, C.-H.: Desorption ionization of biomolecules on metals, Anal. Chem., 80, 5203-5210, 2008.

Hunt, A. L. and Petrucci, G. A.: Analysis of ultrafine and organic particles by aerosol mass spectrometry, Trends Anal. Chem., 21, 74-81, 2002.

Iinuma, Y., Böge, O., Gnauk, T., and Herrmann, H.: Aerosolchamber study of the $\alpha$-pinene $/ \mathrm{O}_{3}$ reaction: influence of particle acidity on aerosol yields and products, Atmos. Environ., 38, 761-773, 2004.

Jimenez, J. L., Canagaratna, M. R., Donahue, N. M., Prevot, A. S. H., Zhang, Q., Kroll, J. H., DeCarlo, P. F., Allan, J. D., Coe, H., Ng, N. L., Aiken, A. C., Docherty, K. S., Ulbrich, I. M., Grieshop, A. P., Robinson, A. L., Duplissy, J., Smith, J. D., Wilson, K. R., Lanz, V. A., Hueglin, C., Sun, Y. L., Tian, J., Laaksonen, A., Raatikainen, T., Rautiainen, J., Vaattovaara, P., Ehn, M., Kulmala, M., Tomlinson, J. M., Collins, D. R., Cubison, M. J., Dunlea, E. J., Huffman, J. A., Onasch, T. B., Alfarra, M. R., Williams, P. I., Bower, K., Kondo, Y., Schneider, J., Drewnick, F., Borrmann, S., Weimer, S., Demerjian, K., Salcedo, D., Cot- trell, L., Griffin, R., Takami, A., Miyoshi, T., Hatakeyama, S., Shimono, A., Sun, J. Y., Zhang, Y. M., Dzepina, K., Kimmel, J. R., Sueper, D., Jayne, J. T., Herndon, S. C., Trimborn, A. M., Williams, L. R., Wood, E. C., Middlebrook, A. M., Kolb, C. E., Baltensperger, U., and Worsnop, D. R.: Evolution of organic aerosols in the atmosphere, Science, 326, 1525-1529, doi:10.1126/science.1180353, 2009.

Kanakidou, M., Seinfeld, J. H., Pandis, S. N., Barnes, I., Dentener, F. J., Facchini, M. C., Van Dingenen, R., Ervens, B., Nenes, A., Nielsen, C. J., Swietlicki, E., Putaud, J. P., Balkanski, Y., Fuzzi, S., Horth, J., Moortgat, G. K., Winterhalter, R., Myhre, C. E. L., Tsigaridis, K., Vignati, E., Stephanou, E. G., and Wilson, J.: Organic aerosol and global climate modelling: a review, Atmos. Chem. Phys., 5, 1053-1123, doi:10.5194/acp-5-1053-2005, 2005.

Kroll, J. H. and Seinfeld, J. H.: Chemistry of secondary organic aerosol: Formation and evolution of low-volatility organics in the atmosphere, Atmos. Environ., 42, 3593-3624, 2008.

LaFranchi, B. W. and Petrucci, G. A.: A comprehensive characterization of photoelectron resonance capture ionization aerosol mass spectrometry for the quantitative and qualitative analysis of organic particulate matter, Int. J. Mass Spectrom., 258, 120-133, doi:10.1016/j.ijms.2006.06.013, 2006.

Larsen, B. R., Di Bella, D., Glasius, M., Winterhalter, R., Jensen, N. R., and Hjorth, J.: Gas-phase $\mathrm{OH}$ oxidation of monoterpenes: Gaseous and particulate products, J. Atmos. Chem., 38, 231-276, 2001.

Liu, P., Ziemann, P. J., Kittelson, D. B., and McMurry, P. H.: Generating particle beams of controlled dimensions and convergence: I. Theory of particle motion in aerodynamic lenses and nozzle expansions, Aerosol Sci. Technol., 22, 293-313, 1995a.

Liu, P., Ziemann, P. J., Kittelson, D. B., and McMurry, P. H.: Generating particle beams of controlled dimensions and divergence: II. Experimental evaluation of particle motion in aerodynamic lenses and nozzle expansions, Aerosol Sci. Technol., 22, 314324, 1995 b.

Mansoori, B. A., Johnston, M. V., and Wexler, A. S.: Quantitation of ionic species in single microdroplets by on-line laser desorption/ionization, Anal. Chem., 66, 3681-3687, 1994.

McKeown, P. J., Johnston, M. V., and Murphy, D. M.: On-line single-particle analysis by laser desorption mass spectrometry, Anal. Chem., 63, 2069-2073, 1991.

Meskhidze, N. and Nenes, A.: Phytoplankton and cloudiness in the Southern Ocean, Science, 314, 1419-1423, doi:10.1126/science.1131779, 2006.

Nash, D. G., Baer, T., and Johnston, M. V.: Aerosol mass spectrometry: An introductory review, Int. J. Mass Spectrom., 258, 2-12, doi:10.1016/j.ijms.2006.09.017, 2006.

Nayak, R. and Knapp, D. R.: Effects of thin-film structural parameters on laser desorption/ionization from porous alumina, Anal. Chem., 79, 4950-4956, 2007.

Ng, N. L., Chhabra, P. S., Chan, A. W. H., Surratt, J. D., Kroll, J. H., Kwan, A. J., McCabe, D. C., Wennberg, P. O., Sorooshian, A., Murphy, S. M., Dalleska, N. F., Flagan, R. C., and Seinfeld, J. H.: Effect of $\mathrm{NO}_{\mathrm{x}}$ level on secondary organic aerosol (SOA) formation from the photooxidation of terpenes, Atmos. Chem. Phys., 7, 5159-5174, doi:10.5194/acp-7-5159-2007, 2007.

Noble, C. A. and Prather, K. A.: Real-time single particle mass spectrometry: A historical review of a quarter century of chem- 
ical analysis of aerosols, Mass Spectrom. Rev., 19, 248-274, 2000.

O’Dowd, C. D., Facchini, M. C., Cavalli, F., Ceburnis, D., Mircea, M., Decesari, S., Fuzzi, S., Yoon, Y. J., and Putaud, J.-P.: Biogenically driven organic contribution to marine aerosol, Nature, 431, 676-680, 2004.

Öktem, B., Tolocka, M. P., and Johnston, M. V.: On-line analysis of organic components in fine and ultrafine particles by photoionization aerosol mass spectrometry, Anal. Chem., 76, 253-261, 2004.

Pöschl, U.: Atmospheric aerosols: composition, transformation, climate and health effects, Angew. Chem. Int. Ed. , 44, 75207540, doi:10.1002/anie.200501122, 2005.

Prather, K. A., Nordmeyer, T., and Salt, K.: Real-time characterization of individual aerosol particles using time-of-flight mass spectrometry, Anal. Chem., 66, 1403-1407, 1994.

Presto, A. A. and Donahue, N. M.: Investigation of $\alpha$-pinene + ozone secondary organic aerosol formation at low total aerosol mass, Environ. Sci. Technol., 40, 3536-3543, 2006.

Robinson, A. L., Subramanian, R., Donahue, N. M., BernardoBricker, A., and Rogge, W. F.: Source apportionment of molecular markers and organic aerosol. 3. Food cooking emissions, Environ. Sci. Technol., 40, 7820-7827, 2006.

Rousell, D. J., Dutta, S. M., Little, M. W., and Murray, K. K.: Matrix-free infrared soft laser desorption/ionization, J. Mass Spectrom., 39, 1182-1189, doi:10.1002/jms.706, 2004.

Seinfeld, J. H. and Pankow, J. F.: Organic atmospheric particulate matter, Annu. Rev. Phys. Chem., 54, 121-140, 2003.

Shen, Z., Thomas, J. J., Averbuj, C., Broo, K. M., Engelhard, M., Crowell, J. E., Finn, M. G., and Siuzdak, G.: Porous silicon as a versatile platform for laser desorption/ionization mass spectrometry, Anal. Chem., 73, 612-619, 2001.

Shilling, J. E., Chen, Q., King, S. M., Rosenoern, T., Kroll, J. H., Worsnop, D. R., DeCarlo, P. F., Aiken, A. C., Sueper, D., Jimenez, J. L., and Martin, S. T.: Loading-dependent elemental composition of $\alpha$-pinene SOA particles, Atmos. Chem. Phys., 9, 771-782, doi:10.5194/acp-9-771-2009, 2009.
Srivastava, A., Pitesky, M. E., Steele, P. T., Tobias, H. J., Fergenson, D. P., Horn, J. M., Russell, S. C., Czerwieniec, G. A., Lebrilla, C. B., Gard, E. E., and Frank, M.: Comprehensive assignment of mass spectral signatures from individual Bacillus atrophaeus spores in matrix-free laser desorption/ionization bioaerosol mass spectrometry, Anal. Chem., 77, 3315-3323, 2005.

Thomas, J. J., Shen, Z., Crowell, J. E., Finn, M. G., and Siuzdak, G.: Desorption/ionization on silicon (DIOS): A diverse mass spectrometry platform for protein characterization, Proc. Natl. Acad. Sci. USA, 98, 4932-4937, doi:10.1073/pnas.081069298, 2001.

Tolocka, M. P., Heaton, K. J., Dreyfus, M. A., Wang, S., Zordan, C. A., Saul, T. D., and Johnston, M. V.: Chemistry and particle inception and growth during $\alpha$-pinene ozonolysis, Environ. Sci. Technol., 40, 1843-1848, 2006.

Wada, Y., Yanagishita, T., and Masuda, H.: Ordered porous alumina geometries and surface metals for surface-assisted laser desorption/ ionization of biomolecules: Possible mechanistic implications of metal surface melting, Anal. Chem., 79, 9122-9127, 2007.

Wei, J., Buriak, J. M., and Siuzdak, G.: Desorption-ionization mass spectrometry on porous silicon, Nature, 399, 243-246, 1999.

Woods III, E., Smith, G. D., Dessiaterik, Y., Baer, T., and Miller, R. E.: Quantitative detection of aromatic compounds in single aerosol particle mass spectrometry, Anal. Chem., 73, 2317-2322, 2001.

Yoon, Y. J., Ceburnis, D., Cavalli, F., Jourdan, O., Putaud, J. P., Decesari, S., Fuzzi, S., Sellegri, K., Jennings, S. G., and O'Dowd, C. D.: Seasonal characteristics of the physicochemical properties of North Atlantic marine atmospheric aerosols, J. Geophys. Res., 112, D04206, doi:10.1029/2005JD007044, 2007.

Yu, J., Cocker III, D. R., Griffin, R. J., Flagan, R. C., and Seinfeld, J. H.: Gas-phase ozone oxidation of monoterpenes: Gaseous and particulate products, J. Atmos. Chem, 34, 207-258, 1999.

Zheng, M., Cass, G. R., Schauer, J. J., and Edgerton, E. S.: Source apportionment of PM2.5 in the southeastern United States using solvent-extractable organic compounds as tracers, Environ. Sci. Technol., 36, 2361-2371, 2002. 